Journal of Engineering and Applied Sciences 15 (1): 283-290, 2020

ISSN: 1816-949X

(C) Medwell Journals, 2020

\title{
Distribution Intensity Model of Retail Logistics Outlets in Metropolitan Scale Cities Based on Spatial Structures
}

\author{
S. Kamran Aksa, Sakti Adji Adisasmita, Muhammad Isran Ramli and Sumarni Hamid Aly \\ Department of Civil Engineering, Hasanuddin University, Gowa Regency, Indonesia
}

\begin{abstract}
This study uses the term distribution intensity of Retail Logistics Outlets (RLO) to see its effect on the dynamics of the development of RLO in the metropolitan area. RLO in Makassar city contributes to the formation of spatial structures. This is seen as a change in the function of the area into services by mushrooming RLO in areas with high density levels. The cause of the change in the emergence of RLO as a pull factor in the movement system in general, so that, it impacts spatial interactions. The researcher considers that this is still a new and very interesting thing to do in this research. The focus is on the effect of RLO on the development of spatial structures in the Metropolitan city of Makassar using the analysis of the distribution of the nearest neighboring regions and linear regression. The results of this study can provide several references for spatial planners in space control policies towards the development of city logistics.
\end{abstract}

Key words: RLO, spatial planning, city logistics, movement, emergence, Makassar

\section{INTRODUCTION}

The city is a space where interaction between residents, activities and economic circulation and the city center is one aspect that is very influential in the surrounding area and has the function of serving the area under the hierarchy. The development of Makassar Metropolitan city currently affects urban transportation problems because the development of transportation is slower than the development of cities, so, transportation planning must pay attention to various aspects and predict future conditions and must be integrated with spatial planning.

The phenomenon in several big cities in Indonesia has been very aggressive retail expansion due to economic globalization triggered the pursuit of consumers with shopping centers (malls) as a medium of commercialization, making the city space dictated. This phenomenon is relatively difficult to control because the market system applies to the presence of modern shopping concepts (Setyawarman, 2009). As a result of the tendency of the development of modern logistics retailers lead to the pattern of decentralization of regions where trade activities include tertiary activities which are service activities such as distribution and exchange of logistics. New retail growth is caused by changes in the density of housing, income, population, qualification of commercial offers according to the type and variety of logistic offered, increased accessibility, road infrastructure, public transportation, new transportation stations (Maraschin and Krafta, 2013). All types of retail outlets must be an integral part of the retail hierarchy, consumer mobility, retail chains and decentralization and zoning regulations and all encourage development outside the city (Burcu et al., 2013). Central place theory can be used as a basis in determining the location of a shopping center that accommodates this trade activity and the shopping center becomes a central place which is a cluster of various trade activities located in certain places and able to provide services to consumers around them (Yeates and Garner, 1980).

The evolution of logistical space is influenced by land prices, accessibility traffic, market demand, agglomeration advantages and government policies (He et al., 2018). From the perspective of urban planning, the logistics subsystem is a process of "fragmentation", related to the number of shipping activities and frequencies that are influenced by distance factors (chain of logistics) and accessibility in distribution (Hesse, 1995). The spatial pattern of retail activity patterns and road network structures illustrates that efficiency is low in the movement towards retail services, differentiation between land use accessibility and movement through and the absence of a dominant city center (Omer and Goldblatt, 2016).

In the context of urban space, it can be observed that the structure of urban space is formed by a framework of road networks, urban infrastructure, population distribution, land use and order/levels of city service systems (Mulyandari, 2011). Factors shape the spatial structure of the cumulative relationship between transportation infrastructure, economic and environmental activities, namely costs (distance factor), accessibility and agglomeration. The structure of a city itself is influenced by land use patterns and networks (Nurkholis, 2002).

Corresponding Author: S. Kamran Aksa, Department of Civil Engineering, Hasanuddin University, Gowa Regency, Indonesia 
Urban spatial structures are shaped by market forces and are influenced by land use regulations, infrastructure investment and taxation (Bertaud, 2004). Logistics economic activities in the formation of space structures namely logistics network, city logistics center, logistics circle and logistics economic zone (Jiang, 2014). The properties of the spatial logistic model are caused by local spread and competition that affect spatial structures which in turn affect population growth (Law et al., 2003). Urban spatial structure refers to a series of relationships that arise from the shape of the city and the underlying interactions between people, logistics and information (Jean-Paul et al., 2013).

\section{MATERIALS AND METHODS}

Location: Distribution of retail logistics outlets spread over 14 sub-districts in 407 by the end of 2017 (Disperindag, Makassar). The development of retail logistics outlets in 2015-2017 increased to $11.20 \%$ with 188 Indomart outlets (46.19\%), 164 Alfamart outlets (40.29\%) and 55 Alfamidi outlets (13.51\%). Furthermore, spatial location assessment can be done using the Geographical Information System (GIS) 10.3.1 (Fig. 1).

Analysis techniques: To see the intensity of Distribution of Retail Logistics Outlets (RLO) of Makassasr city, use the analysis of the nearest neighbors to determine the distribution pattern of the magnitude of the $\mathrm{T}$ value with Eq. 1:

$$
\mathrm{T}=\frac{\overline{\mathrm{Ju}}}{\overline{\mathrm{Jh}}}
$$

Where:

$\mathrm{T}$ : Nearest neighbor index $(\mathrm{T}=0$; group, $\mathrm{T}=1$; random and $\mathrm{T}=2,15$; uniform)

$\overline{\mathrm{Ju}}$ : The average distance is measured between one point and the closest neighbor point

$\overline{\mathrm{Jh}}$ : The average distance is obtained by random patterns $1 / 2 \sqrt{ } \mathrm{P}$

$\mathrm{P}$ : The density of each $\mathrm{km}^{2}$ is the number of points $(\mathrm{N})$ divided by area $\left(\mathrm{km}^{2}\right)(\mathrm{A})$, so, it becomes N/A

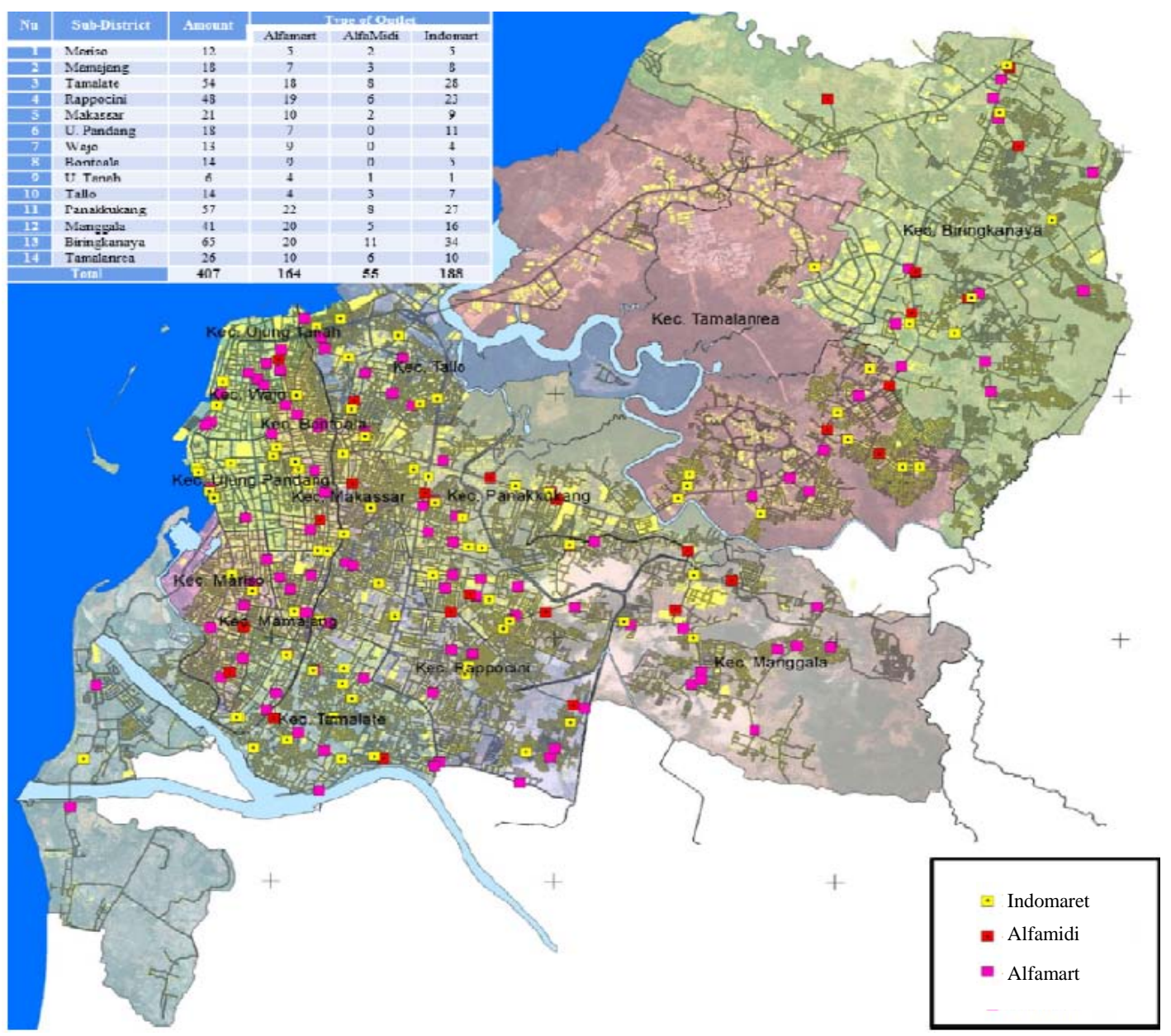

Fig. 1: Distribution of logistics outlet intensity in Makassar city 
J. Eng. Applied Sci., 15 (1): 283-290, 2020

Table 1: Assessment of variables and indicators of space structure

\begin{tabular}{|c|c|c|}
\hline Variables & Assessment indicator & Scoring \\
\hline \multirow{6}{*}{$\overline{X_{1}}$} & Area of district (ha) & \\
\hline & $>4.800$ & 5 \\
\hline & $4.800-3.800$ & 4 \\
\hline & $3.800-2.800$ & 3 \\
\hline & $2.800-1.900$ & 2 \\
\hline & $<1.900$ & 1 \\
\hline \multirow[t]{6}{*}{$\mathbf{X}_{2}$} & Total population (people) & \\
\hline & $>208.436$ & 5 \\
\hline & 208.436-170.851 & 4 \\
\hline & 170.851-133.266 & 3 \\
\hline & 133.266-95.681 & 2 \\
\hline & $<95.681$ & 1 \\
\hline \multirow[t]{6}{*}{$\mathbf{X}_{3}$} & Population density (people $/ \mathrm{km}^{2}$ ) & \\
\hline & $>33.751$ & 5 \\
\hline & $33.751-27.438$ & 4 \\
\hline & 27.438-21.126 & 3 \\
\hline & $21.126-14.813$ & 2 \\
\hline & $<14.813$ & 1 \\
\hline \multirow[t]{6}{*}{$\mathbf{X}_{4}$} & The length of the road $(\mathrm{km})$ & \\
\hline & $>335$ & 5 \\
\hline & $335-273$ & 4 \\
\hline & $273-210$ & 3 \\
\hline & $210-148$ & 2 \\
\hline & $<148$ & 1 \\
\hline \multirow[t]{6}{*}{$\mathbf{X}_{5}$} & RLO transport service (units/week) & \\
\hline & $>18$ & 5 \\
\hline & $17-15$ & 4 \\
\hline & $14-11$ & 3 \\
\hline & $10-7$ & 2 \\
\hline & $<7$ & 1 \\
\hline \multirow[t]{6}{*}{$\mathbf{X}_{6}$} & Connected road section (networks) & \\
\hline & $>5$ & 5 \\
\hline & 4 & 4 \\
\hline & 3 & 3 \\
\hline & 2 & 2 \\
\hline & $<1$ & 1 \\
\hline \multirow[t]{6}{*}{$\mathbf{X}_{7}$} & Accessibility $\left(\mathbf{k m} / \mathbf{k m}^{2}\right)$ & \\
\hline & $>32.69$ & 5 \\
\hline & $32.69-27.15$ & 4 \\
\hline & 27.15-21.61 & 3 \\
\hline & 21.61-16.06 & 2 \\
\hline & $<16.06$ & 1 \\
\hline \multirow[t]{6}{*}{$\mathbf{X}_{8}$} & Income (million/year) & \\
\hline & IDR 19 & 5 \\
\hline & IDR 19-IDR 15 & 4 \\
\hline & IDR 15-IDR 10 & 3 \\
\hline & IDR 10-IDR 5 & 2 \\
\hline & $<$ IDR 5 & 1 \\
\hline
\end{tabular}

Analysis results

To determine the RLO relationship model with space structure variables using multiple regression as done by Breheny and by Santoso et al. (2012) with Eq. 2:

$$
\begin{aligned}
& \underbrace{\mathrm{Y}=}_{\begin{array}{c}
\text { Dependent } \\
\text { variable }
\end{array}} \underbrace{\mathrm{a}+}_{\text {Constant }} \\
& \underbrace{\mathrm{bX}_{1}+\mathrm{bX}_{2}+\mathrm{bX}_{3}+\mathrm{bX}_{4}+\mathrm{bX}_{5}+\mathrm{bX}_{6}+\mathrm{bX}_{7}+\mathrm{bX}_{8}}_{\text {Variable independent }}
\end{aligned}
$$

The method of data analysis using the Program Statistics Program for Special Science (SPSS 24) tests correlation test statistics at intervals of 0.00-0.19 (very low), 0.20-0.39 (low), 0.40-0.59 (moderate), 0.60-0.79 (strong) and 0.80-1.00 (very strong). This assessment uses a Likert scale as in Table 1.

\section{RESULTS AND DISCUSSION}

Basic measurements using the ArcMap. GIS determines the distance radius that is connected between the closest RLO. The distance between RLO in Makassar city is connected between the average distances of $290 \mathrm{~m}$. This shows that every $1 \mathrm{~km}$ there are 1 or 2 retail logistics outlets in the sub-district in the overall context. While each sub-district shows the distance between RLO between 180-450 m with a grouped and diffuse distribution pattern as shown in Fig. 2.

T values tend to be above 1 with a distribution pattern spread across 6 sub-districts, namely Mamajang, Makassar, Ujung Pandang, Wajo, Tallo and Tamalanrea. The pattern of distribution in groups is 8 sub-districts, namely Mariso, Tamalate, Rappocini, Bontoala, Ujung Tanah, Panakkukang, Manggala and Biringkanaya subdistricts. Spatially, Makassar city shows that RLO patterns tend to be clustered with an average $\mathrm{T}$ value of 0.483 (Table 2).

The distribution pattern in the writings found RLO in spread and in groups based on their existence is influenced by location factors. It was also revealed by Petersen (2004) that the layout (spatial distribution) of housing, employment centers, shopping centers, recreation and other activities affected the average length of the trip. High population density with a combination of land use for various socio-economic activities, keeps the distance between origins low. More retail and complementary concentrations between urban retail facilities can mask the shortcomings of polycentric or dispersed areas depending on the distance between cities in a region, retail concentration and spatial competition from neighboring regions (Burger et al., 2014).

The condition of the RLO building is not a permanent place and only a system of contracts or extension of place leases between building owners. So that, the distance between the location/zone and the nearest road is an important factor in choosing a location, however, accessibility is less important for retailers. Spatial interactions with zones that have short-range movements are more attractive to companies. The intensity of the distribution of retail logistics outlets in Makassar city is related to tiered city services following a pattern and forming a hierarchical structure. This is confirmed by Raicu et al. (2009) that the success of reverse logistics with space allocation models with a hierarchical structure of centralized recovery centers depends on product potential, population characteristics, 


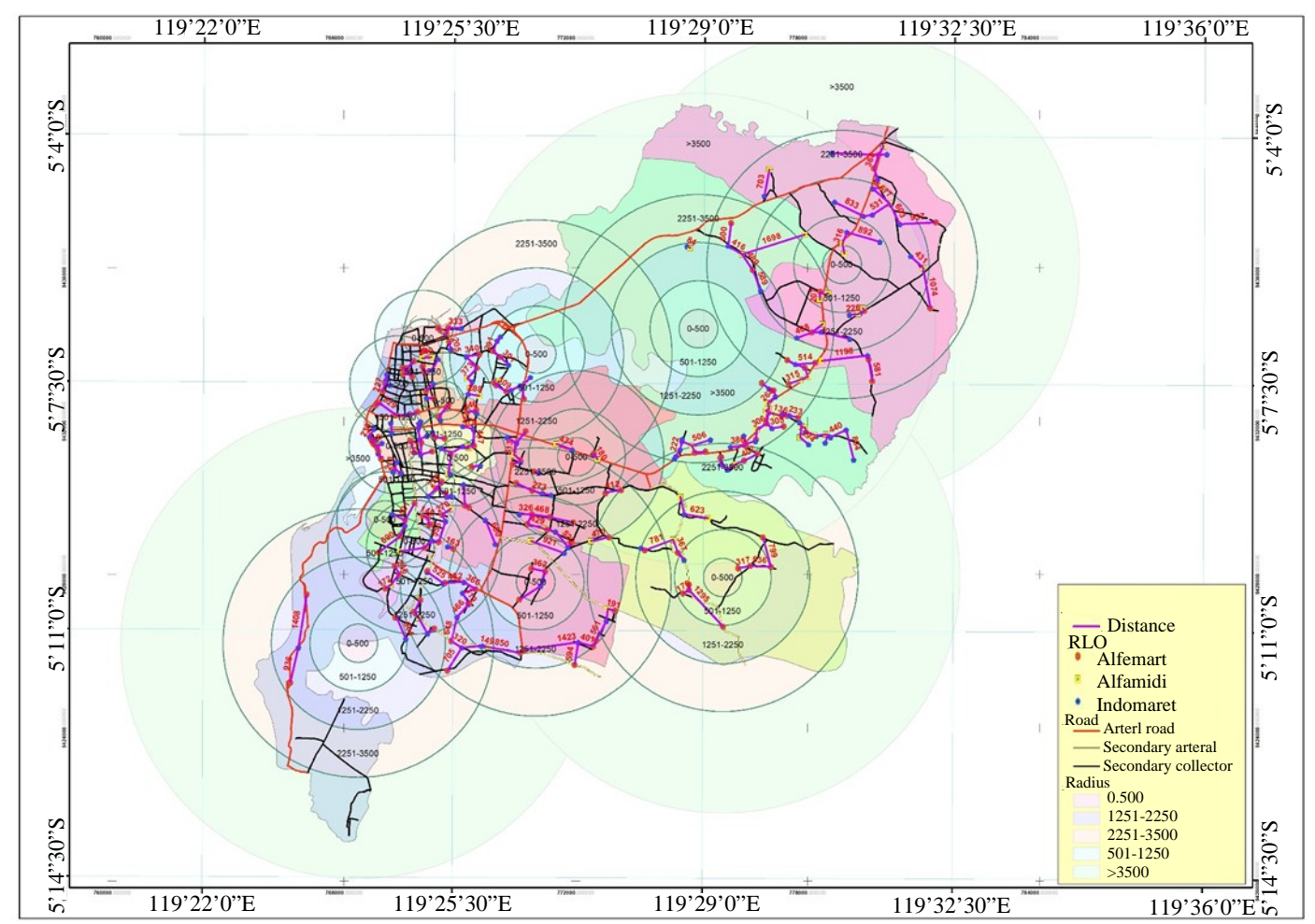

Fig. 2: Radius and distance between RLO

Table 2: The pattern of distribution intensity of Retail Logistics Outlets (RLO) in Makassar city

\begin{tabular}{|c|c|c|c|c|}
\hline Districts & RLO amount & Average distance (m) & t-values & Explanation \\
\hline Mariso & 12 & 404.20 & 0.86 & Group \\
\hline Mamajang & 18 & 272.33 & 1.03 & Spread \\
\hline Tamalate & 54 & 436.61 & 0.61 & Group \\
\hline Rappocini & 48 & 470.75 & 0.72 & Group k \\
\hline Makassar & 21 & 185.18 & 1.12 & Spread \\
\hline Ujung Pandang & 18 & 146.50 & 1.11 & Spread \\
\hline Wajo & 13 & 167.31 & 1.05 & Spread $\mathrm{r}$ \\
\hline Bontoala & 14 & 180.36 & 0.73 & Group \\
\hline Ujung Tanah & 6 & 148.33 & 0.30 & Group \\
\hline Tallo & 14 & 225.10 & 1.05 & Spread \\
\hline Panakkukang & 57 & 285.05 & 0.40 & Group \\
\hline Manggala & 41 & 452.27 & 0.43 & Group \\
\hline Biringkanaya & 65 & 433.65 & 0.53 & Group \\
\hline Tamalanrea & 26 & 248.14 & 1.12 & Spread \\
\hline
\end{tabular}

Analysis results

"moral" incentives, road network structures, transportation and facilities, information flows and policies.

The movement of people can easily be a shopping choice in meeting their needs supported by the convenience system. In the case of this research, the distribution system of retail logistics outlets in the city of Makassar is influenced by the movement system because of the motivation of the desire to shop but not from the motivation of distance factors and time. This was also expressed by Woudsma et al. (2008) that the pattern of development of logistics land is affected by access to certain locations in urban areas such as major highways and airports. Other things can also be attributed to government policy factors in spatial planning that during the alignment of urban development policies that do not refer to the standard planning provisions for the distribution of retail logistics outlets but are more oriented towards developing the corridor, even if it is not intended.

The main factor in decision making in the city logistics according to Onstein et al. (2019) that the level of demand and service, product characteristics, logistics costs, labor and land, accessibility and contextual factors. The main factors influencing the selection of distribution 


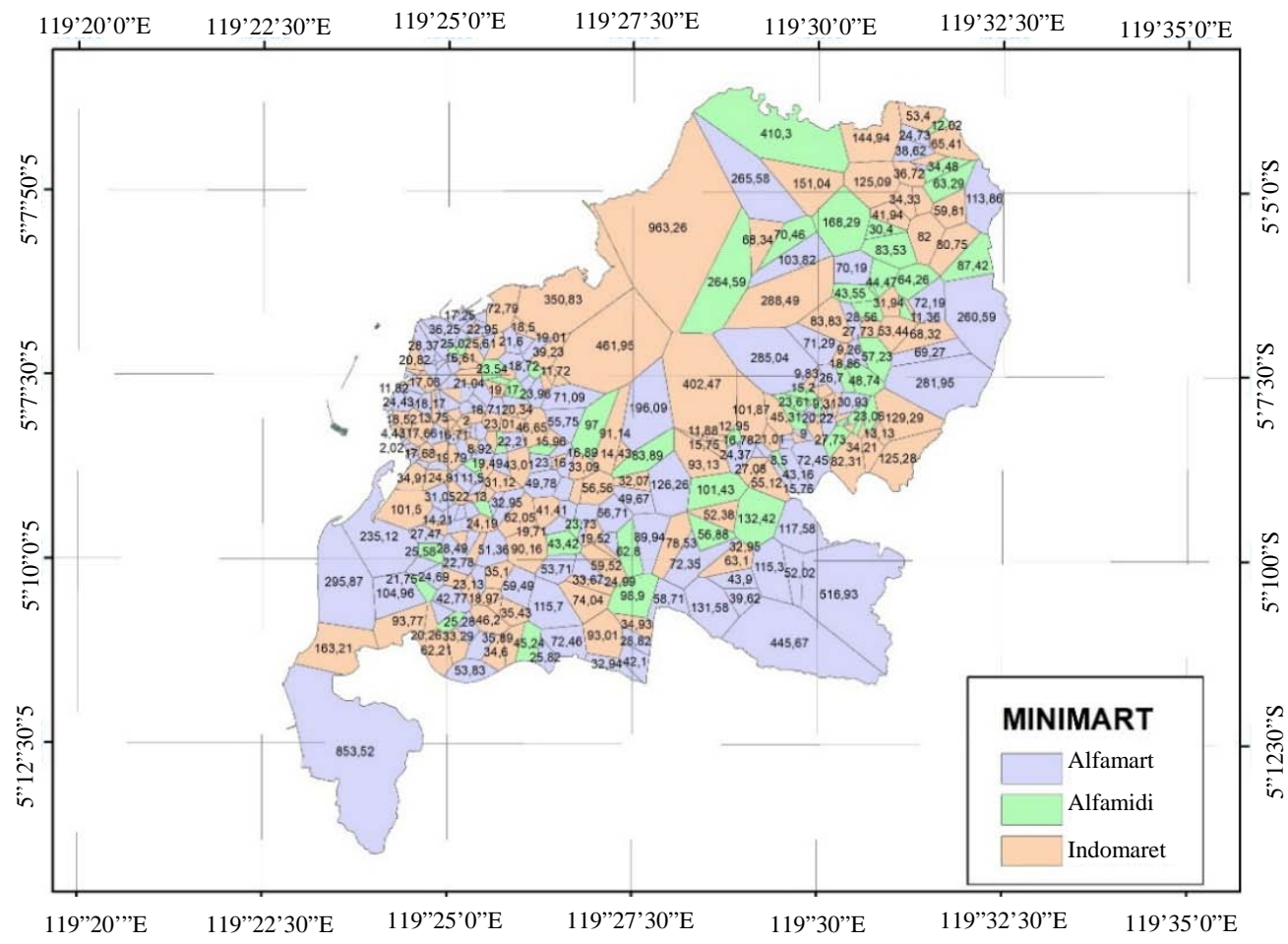

Fig. 3: Retail logistics shop service system in 1 ha

structures are service levels and logistical costs. Heitz et al. (2017) also assumes that the logistics distribution of growth and warehousing in the suburbs is influenced by urban structure factors, spatial planning policies and the quality of the transportation hub of an area. The level of accessibility has no effect on changes in the structure of the city but rather the expansion of land. While the spatial distribution of permanent residents, industrial companies also do not have a significant influence on land development (Yu and Yuefang, 2015).

The transportation node for retail logistics outlets in the city of Makassar is a service network node that draws closer to the public as the final consumer, namely the RLO case, showing that more and more people are near retail retail outlets, the closer the distance is to reducing the number of trips, so that, it is the advantage of the node for supply of logistics. The better the level of accessibility in an urban area, the higher the RLO. Therefore, the distribution of retail logistics outlets in Makassar city can be said that almost all residential areas already have RLO in 1 ha at the density level served by retail retail logistics outlets as shown in Fig. 3.

Almost all regions starting from the center of Makassar city to the central and suburban/border areas have been served by retail logistics outlets and also supported by markets in several sub-districts having more than one market serving the area. The distribution of retail logistics outlets to the logistics transportation nodes surrounding the warehousing area (KIMA) requires logistic transportation services along the arterial and collector road networks as shown in Fig. 4. Road network characterization becomes the main driver of activities in urban ecosystems and structuring factors in urban dynamics towards development distribution of gravity-based retail locations, namely road network location and cluster size depending on the threshold and scale of exponents (Piovani et al., 2017). Likewise, Ji et al. (2013) that the optimization model of the location of regional express distribution centers is based on the reality of road networks by minimizing distance.

According to Hesse and Rodrigue (2004), argues that logistical integration, transportation is not merely considered derivative demand but as an integrated demand in which physical distribution and management of materials are interdependent. Because logistics emerged as the main organizational system for the flow of materials and shipping logistics intensively formed by the traffic of goods and logistics facilities. Ducret et al. (2016) sees that from the point of view of urban transportation is there a relationship between the characteristics of urban forms to the spatial and movement of logistics. The urban transport movement that spatial interaction significantly influences the decision making process with other customers has a greater influence on customers than the interaction between alternative zones (Wisetjindawat et al., 2006). 
Table 3: Results of calculation of coefficient of t-test

\begin{tabular}{lcccc}
\hline Models & Unstandardized coef. $(\beta)$ & t-values & Sig. & df $=$ N-K (0.05) \\
\hline (Constant) & -6.881 & -0.529 & 0.600 & Explanation \\
$\mathrm{X}_{1}$ & -2.554 & -0.646 & 0.522 & - \\
$\mathrm{X}_{2}$ & 3.206 & 0.578 & 0.567 & - \\
$\mathrm{X}_{3}$ & -0.429 & -0.120 & 0.905 & - \\
$\mathrm{X}_{4}$ & 5.090 & 0.964 & 0.342 & - \\
$\mathrm{X}_{5}$ & 6.558 & 2.575 & 0.015 & t count effect \\
$\mathrm{X}_{6}$ & 2.132 & 0.793 & 0.434 & t count effect \\
$\mathrm{X}_{7}$ & -2.113 & -0.639 & 0.527 & t count effect \\
$\mathrm{X}_{8}$ & -1.032 & -0.169 & 0.867 & t count has no effect \\
\hline
\end{tabular}

Results of SPSS calculations

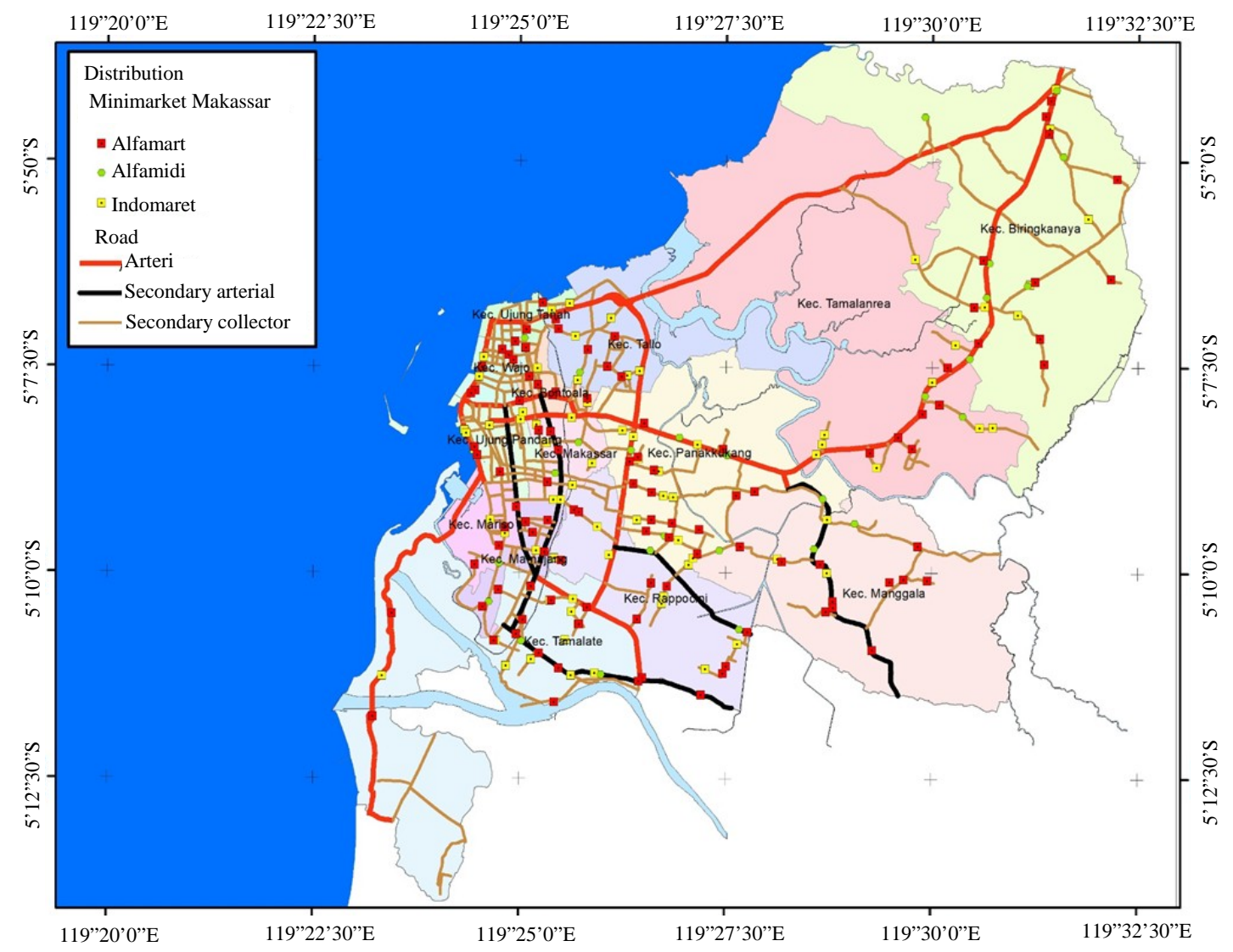

Fig. 4: Distribution of retail logisti outlet distribution systems

$\mathrm{T}$ and $\mathrm{R}^{2}$ tests in multiple linear regression to estimate the equation/multiple linear regression model that explains the behavior of independent variables in influencing the dependent variable. Parameters estimated in linear regression include intercepts (constants) and slope (coefficients in linear equations). According to Sugiyono illustrates that the testing of the t-test is in the $\mathrm{H}_{0}$ reception area or is located between the table prices, then $\mathrm{H}_{\mathrm{o}}$ is accepted and $\mathrm{H}_{\mathrm{a}}$ is rejected as in Fig. 5 and Table 3.

The coverage area that is built becomes a prospect for RLO while the area is still empty land or has not been built in size and the level of crowd is very weak, certainly $\mathrm{RLO}$ is not there. The more RLO at a location becomes a benchmark for the market area with the number of residents to be served. The existence of RLO is always in areas that have high population density. The placement location is on the main road network both arteries, collectors and local tend to always be there. Thus, it can be said that on the road network RLO has potential in strategic locations. The existence of RLO is always related to regular service according to the operating schedule in the smooth distribution of goods to RLO which is the main for fulfilling the stock. The existence of 


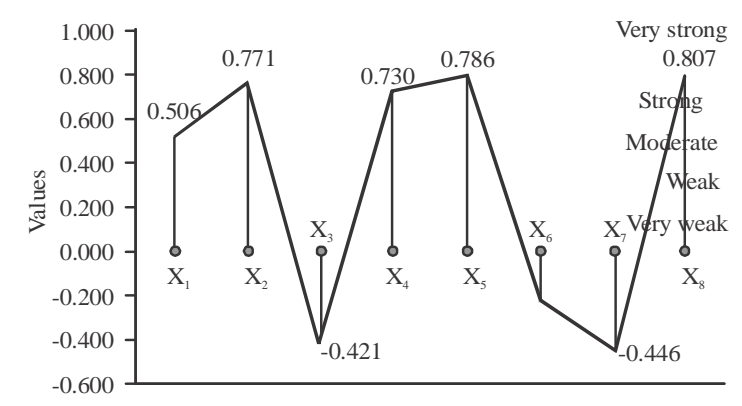

Fig. 5: Pearson RLO correlation graph based on space structure

RLO on road segments that are connected as trajectories for distribution and is an option to avoid congestion on the road. The existence of RLO with a level of affordability by the community is very easy to be located on the main road corridor. The existence of RLO does not see high-income, middle-income or weak-income communities as important services for all people in the community. The mathematical model is shown $\mathrm{Y}=-6.881-2.554 \mathrm{X}_{1}+0.306 \mathrm{X}_{2}-0.429 \mathrm{X}_{3}+$ $5.090 \mathrm{X}_{4}+6.558 \mathrm{X}_{5}+2.132 \mathrm{X}_{6}-2.113 \mathrm{X}_{7}-1.032 \mathrm{X}_{8}$. Based on the coefficient of determination, measured by the variable debt to equity ratio, the adjusted $\mathrm{R}^{2}$ value of 0.735 or $73.5 \%$ is obtained. This means that the proportion of variables $\mathrm{X}_{8}, \mathrm{X}_{7}, \mathrm{X}_{5}, \mathrm{X}_{1}, \mathrm{X}_{4}, \mathrm{X}_{3}, \mathrm{X}_{6}$ and $\mathrm{X}_{2}$ on the ISGLR variable has an influence proportion of $73.5 \%$ while the remaining $26.5 \%$ is influenced by other variables not in the linear regression model.

According to Daniele Patier and Florence Toilier that the challenges of sustainable urban logistics require the development of an Urban Logistics System (ULS) model in overcoming space, place use infrastructure, transportation capacity, etc. to optimize the delivery of urban logistics. Urban Commercial Districts (UCD) must be distributed within cities according to the spatial pattern of the population showing different types of UCD have different spatial distribution features (Wang and Niu, 2019). The spatial layout of logistics facilities and companies correlates significantly with industry demand and location affected by demand for consumption and distribution as well as the socio-economic conditions of the population. Logistics industry distribution shows the spatial characteristics of "single-center and many-center" or “many-center and several centers” (Guoqi et al., 2015). In the establishment of logistical spatial locations the role of the government is to regulate transportation routes and the location of transport stations and control the leasing of land for the logistics space (Li et al., 2017).

In the case of RLO in Makassar city in the context of urban development, the distribution of retail logistics outlets as one of the availability of trade/infrastructure facilities (warehousing), residents domiciled increasingly disliked because it caused development conflicts coupled with increasingly expensive land prices. The expression is rather difficult to do considering the limited land, so that, by itself retail entrepreneurs make a breakthrough by transferring the function of the building into a RLO with a contract system.

\section{CONCLUSION}

RLO on built-in area coverage is a prospect for RLO while the area is still empty land or has not yet been built, certainly RLO is not available. RLO more and more locations become a benchmark for market areas with underserved population and high density. RLO tends to be on the main road network both arterial, collector and local and strategic. Regular service according to the schedule for the smooth distribution of logistics to RLO for the fulfillment of stock and does not interfere with traffic jams. Network road links are connected until the final destination RLO is only an option to avoid congestion on the road. The level of affordability of the people is very easy to be on the main road corridor without seeing far or near the choice. Do not see the income of high, middle and low class people but for daily needs. The novelty of this study in this case is that the distribution service system in RLO does not affect the spatial structure associated with accessibility which means that the more RLO, the accessibility level is not the closest choice but another RLO. The existence of ISGLR in the metrolopolitan city of Makassar always forms a group pattern within 250-500.

\section{RECOMMENDATIONS}

It is hoped that further research can be carried out based on the results of the $\mathrm{R}^{2}$ determination coefficient value of 0.735 or $73.5 \%$. This means that the proportion of variable influences from 8 variables is still influenced by $26.5 \%$ of other variables.

\section{ACKNOWLEDGEMENT}

This research is a BPPDN scholarship program for doctoral education by the Indonesian Ministry of Research, Technology and Higher Education (DIKTI) and the Faculty of Engineering, Regional and city Planning Study Program, Bosowa Makassar University.

\section{REFERENCES}

Bertaud, A., 2004. The spatial organization of cities: Deliberate outcome or unforeseen consequence?. Institute of Urban and Regional Development, University of California at Berkeley, Berkeley, California, USA.https://austinzoning.typepad. com/austincontrarian/files/WP-2004-01.pdf 
Burcu, H., Ozuduru and G. Jean-Michel, 2013. Retail location and urban resilience: Towards a new framework for retail policy. SAPIENS., Vol. 6,

Burger, M.J., E.J. Meijers and F.G. Van Oort, 2014. Regional spatial structure and retail amenities in the Netherlands. Reg. Stud., 48: 1972-1992.

Ducret, R., B. Lemarie and A. Roset, 2016. Cluster analysis and spatial modeling for urban freight: Identifying homogeneous urban zones based on urban form and logistics characteristics. Transp. Res. Procedia, 12: 301-313.

Guoqi, L., J. Fengjun, C. Yu and L.I.U. Sijing, 2015. Spatial patterns of logistics industry based on a geographic analysis of hotness degree. Prog. Geogr., 34: 629-637.

He, M., J. Shen, X. Wu and J. Luo, 2018. Logistics space: A literature review from the sustainability perspective. Sustainability, 10: 1-24.

Heitz, A., L. Dablanc and L.A. Tavasszy, 2017. Logistics sprawl in monocentric and polycentric metropolitan areas: The cases of Paris, France and the Randstad, the Netherlands. Reg., 4: 93-107.

Hesse, M. and J.P. Rodrigue, 2004. The transport geography of logistics and freight distribution. J. Transp. Geography, 12: 171-184.

Hesse, M., 1995. Urban space and logistics: On the road to sustainability?. World Trans. Policy Pract., 1: 39-45.

Jean-Paul, R., C. Comtois and B. Slack, 2013. The Geography of Transport Systems. 3rd Edn., Routledge, Abingdon, UK., ISBN:978-0-415-822534, Pages: 416.

Ji, Y., H. Yang, Y. Zhang and W. Zhong, 2013. Location optimization model of regional express distribution center. Procedia Soc. Behav. Sci., 96: 1008-1013.

Jiang, Z., 2014. Research on interference of spatial construction mode with logistics technology. Proceedings of the 3rd International Conference on Science and Social Research (ICSSR 2014), June 14-15, 2014, Atlantis Press, Paris, ISBN: 978-94-6252-009-7, pp: 840-844.

Law, R., D.J. Murrell and U. Dieckmann, 2003. Population growth in space and time: Spatial logistic equations. Ecology, 84: 252-262.

Li, G., F. Jin, Y. Chen, J. Jiao and S. Liu, 2017. Location characteristics and differentiation mechanism of logistics nodes and logistics enterprises based on Points of Interest (POI): A case study of Beijing. J. Geogr. Sci., 27: 879-896.

Maraschin, C. and R. Krafta, 2013. Growth dynamic of retail locations: A methodological approach using a logistic model. Cybergeo Eur. J. Geogr., Vol. 1,
Mulyandari, H., 2011. Introduction to city Architecture. CV Andi Offset Publishers, Depok, Indonesia,.

Nurkholis, 2002. The pattern of commercial goods transport in the city of Semarang. Master Thesis, Diponegoro University, Semarang, Indonesia.

Omer, I. and R. Goldblatt, 2016. Spatial patterns of retail activity and street network structure in new and traditional Israeli cities. Urban Geogr., 37: 629-649.

Onstein, A.T., L.A. Tavasszy and D.A. van Damme, 2019. Factors determining distribution structure decisions in logistics: A literature review and research agenda. Trans. Rev., 39: 243-260.

Petersen, R., 2004. Land use planning and urban transport, module 2a sustainable transportation: A guide for policy makers in developing cities. Deutsche Gesellschaft für Internationale Zusammenarbeit (GIZ), Eschborn, Germany.

Piovani, D., C. Molinero and A. Wilson, 2017. Urban retail location: Insights from percolation theory and spatial interaction modeling. PloS One, Vol. 12, 10.1371/journal.pone.018578

Raicu, S., M. Popa, E. Rosca and V. Dragu, 2009. Reverse logistics and space allocation for recovery management in new Urban Settlements. Theor. Empirical Researches Urban Manage., 3: 37-48.

Santoso, E.B., U. Ema and U.A. Belinda, 2012. Dictate analysis and location of spatial patterns: Urban and regional planning engineering. Sepuluh Nopember Institute of Technology (ITS), Surabaya, Indonesia.

Setyawarman, A., 2009. Distribution patterns and factors affecting the selection of modern retail locations (case study of Surakarta City). Master Thesis, Diponegoro University, Semarang, Indonesia.

Wang, F. and F.Q. Niu, 2019. Urban commercial spatial structure optimization in the metropolitan area of Beijing: A microscopic perspective. Sustainability, 11: 1-18.

Wisetjindawat, W., K. Sano and S. Matsumoto, 2006. Commodity distribution model incorporating spatial interactions for urban freight movement. Proceedings of the 85th Annual Meeting on the Transportation Research Board, January 22-26, 2006, Washington DC., USA., pp: 1-20.

Woudsma, C., J.F. Jensen, P. Kanaroglou and H. Maoh, 2008. Logistics land use and the city: A spatialtemporal modeling approach. Transp. Res. Part E: Logist. Transp. Rev., 44: 277-297.

Yeates, M.H. and B.J. Garner, 1980. North American City. 3rd Edn., Harper and Row Publishers, New York, USA., ISBN-13:978-0060473341, Pages: 557.

Yu, D.E.N.G. and S.I. Yuefang, 2015. The spatial pattern and influence factors of urban expansion: A case study of Beijing. Geog. Res., 34: 2247-2256. 